\title{
The Impacts of Forest Plantation on Household's Income
}

\author{
Tran Cuong1,2*, Tran Thi Quy Chinh ${ }^{1,3}$, Yi Xie $^{1}$ \\ ${ }^{1}$ School of Economics and Management, Beijing Forestry University, Beijing, China \\ ${ }^{2}$ Department of Economic and rural development, Thai Nguyen University of Agriculture and Forestry, Thai Nguyen, Vietnam \\ ${ }^{3}$ Sao Do University, Chi Linh, Vietnam \\ Email: *trancuong2288@gmail.com,dhnl@tuaf.edu.vn,info@saodo.edu.vn
}

How to cite this paper: Cuong, T., Chinh, T.T.Q. and Xie, Y. (2019) The Impacts of Forest Plantation on Household's Income. Open Access Library Journal, 6: e5587. https://doi.org/10.4236/oalib.1105587

Received: July 9, 2019

Accepted: July 28, 2019

Published: July 31, 2019

Copyright $\odot 2019$ by author(s) and Open Access Library Inc.

This work is licensed under the Creative Commons Attribution International License (CC BY 4.0).

http://creativecommons.org/licenses/by/4.0/

\begin{abstract}
This study uses differences in differences (DID) method combined with OLS regression to assess the impact of forest plantations on household income and livelihoods in rural areas of Bac Kan Province in Vietnam based on the 2017 household living standard field survey data and VRAFC 2011 database. Results indicated that forest plantations have no impact on improving the household's income. This is explained by income from forest plantation that is uneven among households in 2017 and household's income survey data that is often inaccurate because the prolongation of the production cycle in planted forest activities and error in income calculate. On the other hand, the study also found the impact of households gender, off-farm employment, household size, a land area owned, land security and rural credit on incomes and expenditure of households in the study area. We recommend that some policies such as land tenure reform, diversification economic activities and rural employment, to enhance the ability to access resources and improve capacity participation in non-farm activities should be proposed to help improve households living standards in rural areas of Bac Kan Province in particular and Vietnam in general.
\end{abstract}

\section{Subject Areas \\ Environmental Economics}

\section{Keywords}

Household's Income, Forest Plantation, Impact, DID Method 


\section{Introduction}

As the world becomes more and more interested in addressing climate change issues, the effect and impact of deforestation and forest degradation on climate are also getting more and more focused. This issue helps confirm the important role of the forest as a green lung of humankind, helping to regulate the climate and sustain life on earth. On the other hand, forests also play a large role in poverty reduction and livelihood improvement of people around the world, which is reflected in reports and articles published worldwide, e.g. improve livelihoods, generate income and employment, provide safety networks to minimize risks, provide firewood for farmers or it has a role as a savings mechanism and cash allowance [1] [2] [3] [4].

Furthermore, studies in the world evaluating the impact of forest plantations on household income have majority focused on commercial forests plantation developed by enterprises. These studies have shown that the forest plantations have potential benefits from increasing forestry income, improving infrastructure, diversification of income sources and creating jobs [5] [6] [7] [8] [9]. On the other hand, these studies also indicated that poverty levels become more serious in areas where commercial plantation forests had expanded [4] [10]-[15]. Only a few studies have evaluated the contribution forest plantations to rural livelihoods of farm households in the world [16] [17] [18] [19].

The forestry sector is considered to play an important role in economic development in Bac Kan province. In recent years, along with innovations in management, scientific research activities in the forestry sector and development of forest planting techniques have also received more attention. Forest planting programs and projects are implemented on a provincial scale with many production plantation models established, many technical measures have been developed into processes, thence help improve and enhance the efficiency of afforestation activities [20].

In addition, to our knowledge, there is no empirical evidence on whether or not a participation in plantation improves the income of the participant farm households; no specific research has been done to assess the impact forest plantation to improve farm household's income in the rural area of Vietnam. Most of the research has been done in relation to plantation development focusing on the economic efficiency of a particular crop, the development of the wood processing industry, and the policy for payment for forest environmental services (PES) and forest land allocation policies [21]-[26]. Hence, this study attempts to provide empirical evidence on the impact of forest plantations on household cash income in the study areas.

In order to assessing the impact of forest plantations to farm household income in Bac Kan province of Vietnam, this study will: 1) evaluate the factors affect to household's income in study area; 2) evaluate the impact of smallholder plantation on economic benefits (total cash income and use of improved agricultural input) of the forest planting participant farm households in study area. 
Thence, the study will provide policymakers with the necessary data for policy adjustment and proposes the solutions help to improve income and rural livelihoods of households in the context of each specific area in the future.

\section{Materials and Methods}

\subsection{The Study Area}

Bac Kan province is located on the North East extension of Vietnam $\left(22^{\circ} \mathrm{N}\right.$ $23^{\circ} \mathrm{N}, 105^{\circ} \mathrm{E}-106^{\circ} \mathrm{E}$ ) (Figure 1). The province with population of 308,300 and $81.24 \%$ of the population living in a rural area, and composed predominantly of ethnic minorities, including Tay, Nung, Kinh, Dao, Mong, Hoa, San Chay, and others [27]. With a land area of $4859 \mathrm{~km}^{2}, \mathrm{Bac}$ Kan is the smallest province in the north of Vietnam and has a relatively low population density compared to the provincial average ( 63 person per $\mathrm{km}^{2}$ compared to 314 person per $\mathrm{km}^{2}$ ). The climate is subtropical monsoonal with hot wet in the summers and cool, dry in the winters.

\subsection{Data Collection}

We adopted a combination of secondary data and field survey data collection in this study. Primary data were collected covering the period from June to August in 2017, were conducted with household heads (or another senior household member), using household survey, focus group discussions and key informant interviews. The surveys and interviews were conducted by the author and six local enumerators. Vietnamese or ethnic languages were used (as required) to conduct the surveys, with the data recorded in Vietnamese, and then later translated into English by an author (with crosschecking and random back-translations by

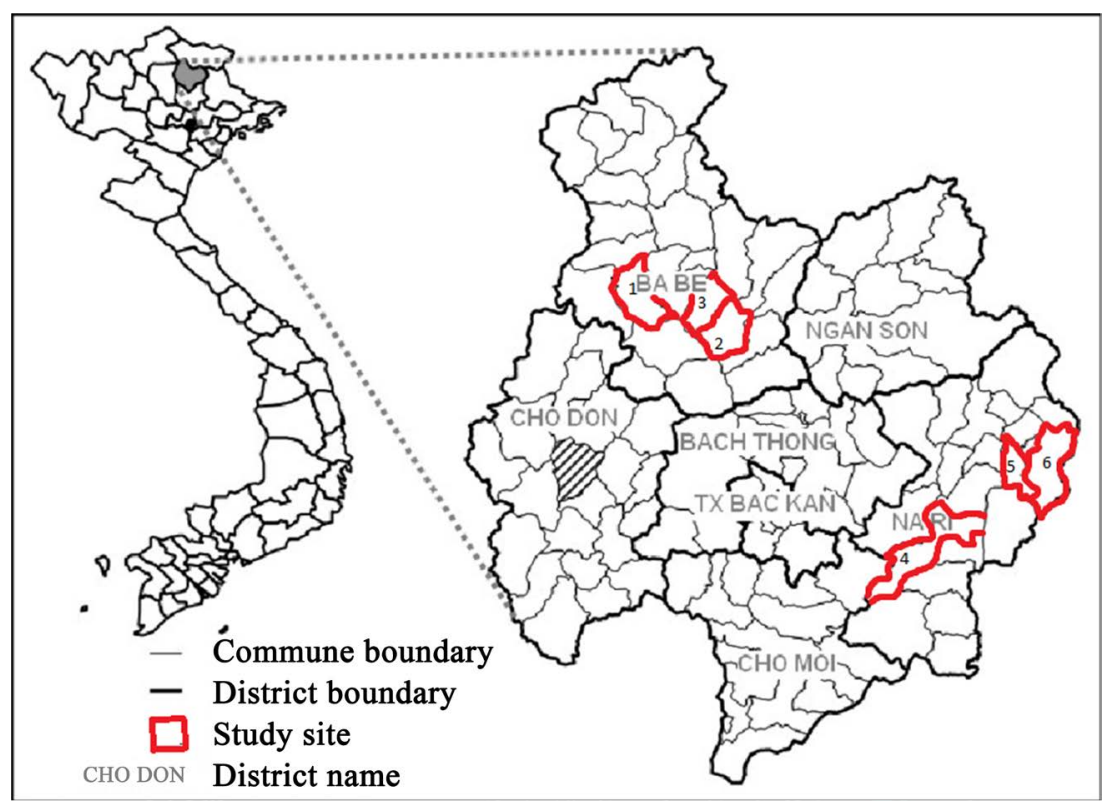

Source: Department of Natural Resources and Environment of Bac Kan.

Figure 1. Diagram showing Vietnam and the study area in Bac Kan Province. 
author's colleague to ensure the quality).

The secondary data collected in 2011 by Vietnam Central Planning Committee and General Statistics Office (GSO) in the Vietnam Rural, Agricultural and Fishery Census (VRAFC). The survey sample was selected to be representative for the whole country. The selection of the sample followed a method of stratified random sampling (see GSO, 2011, 2016 for a more detail).

At the same time, because of the large forest land area in Bac Kan and the discrete distribution of the different species, we made use of the average data for the cost and revenue of plantations in recent years to reflect the average level of economic analysis.

\subsection{The Analytical Model}

To modeling the participation of farmers in afforestation activities and impact of forest plantations on income of farm households, the study followed researches of [15] [17] [28] [29]. The difference-in-difference model to explain the variation on income of farm household's base on the impact of forest plantation written in the formula:

$$
H I_{i t}=\beta_{0}+\beta_{1} D+\beta_{2} T+\beta_{3} D * T+\beta_{4} Z_{i t}+\varepsilon_{i t}
$$

In which

$H I_{i t}$ the indicator reflect the households income $i$ in period $t$.

$D=0$ : Survey households belong to control group (comparison group).

$D=1$ : Survey households belong to participating group (intervention group).

$T=0$ : Survey households in 2011.

$T=1$ : Survey households in 2017.

$Z_{i t}$ is a vector of the control variables help to explain variation in the farm household's income: including variable groups reflect households head and household's characteristics, production capacity of households, institutional and policy variables.

The $\beta_{i}$ are parameters to be estimated and $\varepsilon_{i t}$ is the error term.

Households in the control group in 2011 had $D=0$ and $T=0$ so the total income was:

$$
E\left(H I_{00}\right)=\beta_{0}+\beta_{4} Z_{i t}
$$

Households in the participating group in 2011 had $D=1$ and $T=0$ so the total income was:

$$
E\left(H I_{10}\right)=\beta_{0}+\beta_{1}+\beta_{4} Z_{i t}
$$

$=>$ The income difference between the two household groups in 2011 was:

$$
E\left(H I_{10}\right)-E\left(H I_{00}\right)=\beta_{1}
$$

Households in the control group in 2017 had $D=0$ and $T=1$ so the total income was:

$$
E\left(H I_{01}\right)=\beta_{0}+\beta_{2}+\beta_{4} Z_{i t}
$$

Households in the participating group in 2017 had $D=1$ and $T=1$ so the to- 
tal income was:

$$
E\left(H I_{11}\right)=\beta_{0}+\beta_{1}+\beta_{2}+\beta_{3}+\beta_{4} Z_{i t}
$$

$=>$ The income difference between the two household groups in 2017 was:

$$
E\left(H I_{11}\right)-E\left(H I_{01}\right)=\beta_{1}+\beta_{3}
$$

$=>$ The impact of forest plantation on farm household's income is:

$$
D I D=\left[E\left(H I_{11}\right)-E\left(H I_{01}\right)\right]-\left[E\left(H I_{10}\right)-E\left(H I_{00}\right)\right]=\beta_{3}
$$

Equation (2) represents the impact of forest plantation on farm household's income by sampled households with incorporating thirteen variables (shown in Table 1). It is representing household, policy/institution factors, the difference in time of the field surveys, forest plantation decision and interaction between these two variables.

Table 1. Explanatory variables in DID model.

Explanatory variable Summary symbol Variables description

1. Dependent variable

Households income

AINCOME

\section{Independent variable}

2.1 Participates plantation activities PLANT

2.2 Survey time

2.3 Interaction of forest plantation $T^{*}$ PLANT and time dummy

Characteristics of the head of the household

$\begin{array}{lll}2.4 & \text { Gender } & \text { GENDER } \\ 2.5 & \text { Age } & A G E \\ 2.6 & \text { Education } & \text { EDU }\end{array}$

Household characteristics

2.7 Household size

HSIZE

2.8 Area of land owned

LSIZE

2.9 Distance from forest plantation DISTAN to a market center or road

2.10 Off-farm work

OFFWORK

Institutional and policy factors

2.11 Land security

LSECUR

2.12 Extension activities

EXTEN

2.13 Loans

$L O A N$
The average amount of household cash income in 2011 and 2017 which is generated from different income generating activities (from the crop, wages, livestock, forestry, off-farm activities and sell their products, etc.) (Million VND). ${ }^{1}$

Dummy, Equals 1 if the household participates in plantation activities and 0 otherwise.

Dummy, Equals 1 if the survey time in 2017 and 0 if survey time in 2011.

The interaction term $T^{\star} P L A N T$ is an indicator for the farm households in the intervention site, and it measures the percentage change in households income associated with the plantation decision. The coefficient on the interaction term $\left(\beta_{3}\right)$ yields the difference-in-difference estimate of the control effect.

Dummy, gender of the household head $(1=$ male and $0=$ female $)$.

Age of the household head in years.

Number of years of schooling of head of household.

Number of individual members in a household.

Size of household's land (hectares).

Distance from the household's house to a market center (kilometers).

Dummy, equals 1 if the household has a member participating in off-farm work and 0 otherwise.

Dummy, equals 1 if secure and 0 otherwise.

Number of days per year in which agricultural extension workers visited the household.

Dummy, LOAN $=1$ if households got any loans and $=0$ if otherwise.

${ }^{1} 1$ Million VND $=44.59$ US\$. 
In order to determine the appropriate model, the paper will conduct implement according to the steps:

Step one, regression the basic model (using explanatory variables: PLANT, T and $\left.T^{*} P L A N T\right)$ to determine if there is no impact of other factors, forest plantation has an impact on income of farm households in rural areas in overtime or not.

Step two, implement develop an extended model (with the effect of other factors beyond the forest plantation) using the method "top-down approach", from general to simple. Specifically:

Firstly: Based on the theoretical framework and previous studies, by linear regression model with all the relevant variables shown above, the paper gives an initial general model.

Secondly: Evaluate the suitability of the model based on adjusted $\mathrm{P}$-value, $\mathrm{R}^{2}$ and $\mathrm{R}^{2}$ Adjusted; remove variables that are insignificant statistically out of the model and select the "best" model.

Thirdly: Check and overcome errors in linear regression models such as multicollinearity phenomenon, Heteroskedasticity phenomenon.

In conclusion, the combination between OLS regression method and DID methods will show that whether forest plantation has a positive impact on the income of rural households in Bac Kan, and how is the level of these impacts (show by the value of $T^{*} P L A N T$ variable). Thence, propose certain interventions to improve the living standard for farm households in rural area of Vietnam.

\section{Results and Discussions}

\subsection{Descriptive Statistics and Examine Statistic Significantly}

The field survey results show that, in 2011, two groups of households have similar characteristics such as age, education of household head, off-farm work, characteristics of household, demographic characteristics, per capita income, per capita expenditure of household, etc. However, there are some different characteristics between these two groups of households such as gender, occupations of the household heads, loan of households etc. Therefore, in order to conclude whether there is really a difference between the two groups, we are necessary to perform a T-test on the average difference between the two groups of households (see Table 2) with the hypothesis:

$H_{0}$ : There is no difference between the two groups (Average value $_{\text {Participant }}=$ Average $_{\text {Control }}$ ).

$H_{1}$ : There is difference between the two groups (Average value $e_{\text {Participant }} \neq$ Average $\left._{\text {Control }}\right)$.

The results showed that, at a statistically significant level of $5 \%$, reject the $\mathrm{H}_{1}$ hypothesis that there is a difference between the control group and the participant group. In other words, these two groups have quite similar characteristics in 2011 year, it detailed in the following the table below: 
Table 2. Descriptive statistics and statistic significantly test between two groups in 2011 .

\begin{tabular}{cccccc}
\hline \multirow{2}{*}{ Indicator } & \multicolumn{2}{c}{ Control group $(\mathrm{n}=\mathbf{7 3})$} & \multicolumn{2}{c}{ Participant group $(\mathrm{n}=287)$} & \multirow{2}{*}{ T-test* } \\
\cline { 2 - 5 } & Mean & Std. Dev & Mean & Std. Dev & \\
\hline AINCOME & 15.057 & 12.728 & 15.493 & 9.991 & -0.313 \\
GENDER & 0.781 & 0.417 & 0.801 & 0.399 & -0.389 \\
AGE & 46.507 & 15.825 & 46.328 & 9.748 & 0.122 \\
EDU & 6.425 & 3.933 & 7.045 & 3.096 & -1.443 \\
HSIZE & 3.986 & 1.161 & 3.791 & 1.167 & 1.278 \\
LSIZE & 1.725 & 2.781 & 1.751 & 1.473 & -0.108 \\
DISTANCE & 3.758 & 2.199 & 3.453 & 2.115 & 1.089 \\
OFFWORK & 0.384 & 0.489 & 0.338 & 0.474 & 0.729 \\
LSECUR & 0.630 & 0.486 & 0.641 & 0.481 & -0.174 \\
EXTEN & 3.110 & 1.688 & 3.429 & 2.549 & -1.014 \\
LOAN & 0.425 & 0.498 & 0.530 & 0.500 & -1.603 \\
\hline
\end{tabular}

Source: Field survey of author, 2017; Notes: Asterisks are significance levels at 5\%.

\subsection{Analyzing the Impacts of Forest Plantation on Household's Income}

In order to assess whether forest plantation helps to improve the household's livelihoods in study area, this study examines the impact of forest plantation on households' income by Differences in Differences method combine OLS regression. White-test shows that there is a phenomenon of heteroskedasticity (HET) so the author repaired by the robust command in Stata (The results are presented in Appendix 1,2 and 3).

The regression results from model 1 show that the average income of households tends to increase from 2011 to 2017. Interaction variable ( $\left.T^{*} P L A N T\right)$ measure Differences in Differences are significant statistic. This means that the model could demonstrate that there is a difference in per capita income between the non-forest plantation group and forest plantation group. However, the value $\mathrm{R}^{2}$ and $\mathrm{R}^{2}$ adjusted of the model 1 have a low value, approximately $8.85 \%$ also shows the low level of relevance of the model.

Furthermore, there are many other factors that affect to the households income, so it is not reasonable to not include these factors in this model. Therefore, the paper conducts regression in the expanded model (model 2). When adding other control variables to the model, the results in the regression model 2 indicate that the per capita income of households in the study area has increased in overtime and have statistically significant. The independent variables in the model also explain $53.41 \%$ of the change of the dependent variable (average income) in the model. However, the variables show the difference in difference ( $T^{*}$ PLANT) is insignificant statistically (Table 3 ). In other words, the expanded model has demonstrated that there is no difference in per capita income between the two household groups. 
Table 3. Estimate the impact of forest plantation on the average per capita income of households.

\begin{tabular}{|c|c|c|c|}
\hline \multirow{2}{*}{ Variables } & Model 1 & Model 2 & Model 3 \\
\hline & Coefficient & Coefficient & Coefficient \\
\hline CONSTANT & $15.057(10.15)^{\star * *}$ & $23.659(7.66)^{\star * *}$ & $25.148(9.02)^{* \star *}$ \\
\hline PLANT & $0.435(0.27)$ & $-0.843(-0.70)$ & $-0.861(-0.71)$ \\
\hline$T$ & $-0.200(-0.10)$ & $3.621(2.34)$ & $3.559(2.30)$ \\
\hline$T^{*} P L A N T$ & $9.719(4.03)^{* * *}$ & $1.792(1.02)$ & $2.044(1.16)$ \\
\hline GENDER & - & $-1.932(-1.74)^{\star}$ & $-1.921(-1.76)^{\star}$ \\
\hline$A G E$ & - & $0.033(1.14)$ & - \\
\hline$E D U$ & - & $-0.041(-0.31)$ & - \\
\hline$H S I Z E$ & - & $-3.197(-7.59)^{\star * \star}$ & $-3.183(-7.29)^{* * *}$ \\
\hline LSIZE & - & $3.374(6.12)^{\star * *}$ & $3.385(6.15)^{* * *}$ \\
\hline DISTAN & - & $-1.597(-7.53)^{\star * *}$ & $-1.618(-7.28)^{* * *}$ \\
\hline OFFWORK & - & $5.063(5.33)^{* * *}$ & $4.902(5.13)^{* * *}$ \\
\hline LSECUR & - & $1.606(2.02)^{\star \star}$ & $1.729(2.13)^{\star *}$ \\
\hline EXTEN & - & $0.065(0.30)$ & - \\
\hline \multirow[t]{7}{*}{$L O A N$} & - & $3.276(4.01)^{\star * *}$ & $3.223(3.96)^{* * *}$ \\
\hline & $\mathrm{n}=720$ & $\mathrm{n}=720$ & $\mathrm{n}=720$ \\
\hline & $\mathrm{R}^{2}: 0.0885$ & $\mathrm{R}^{2}: 0.5341$ & $\mathrm{R}^{2}: 0.5334$ \\
\hline & $\mathrm{R}^{2}$ Adjusted: 0.0847 & $\mathrm{R}^{2}$ Adjusted: 0.5255 & $\mathrm{R}^{2}$ Adjusted: 0.5269 \\
\hline & Prob. $>$ Chi $^{2}: 0.000$ & Prob. $>$ Chi $^{2}: 0.000$ & Prob. > Chi ${ }^{2}: 0.000$ \\
\hline & F value: 18.43 & F-value: 38.45 & F value: 81.06 \\
\hline & Durbin-Watson: 1.332 & Durbin-Watson: 1.495 & Durbin-Watson: 1.496 \\
\hline
\end{tabular}

Notes: Asterisks ${ }^{* * *},{ }^{* *},{ }^{*}$ are significance levels at $1 \%, 5 \%$ and $10 \%$, respectively.

In the regression model 3, the author uses Wald-test to eliminate insignificant variables in the regression model 2 (Appendix 4). In addition, the results of statistical test of the suitability of the model (Appendix 5) show that $P$-value (F-statistic) $<1 \%$ and $\mathrm{R}^{2}$ of regression model 3 approximates model 2 and larger than model 1. This demonstrates that the regression model 3 explains better other models of the factors affecting to income of households; therefore, the final model should be accepted as model 3. Results from the regression model 3 also show that the variables such as age $(A G E)$, education level $(E D U)$ of the household head did not affect the per capita income of households in the study area. This shows that household income does not necessarily depend on the anthropological characteristics of the household head, it seems to depend on opportunity access to resources and input factors in production process. On the other hand, the characteristics of number of days per year in which agricultural extension workers visited the household (EXTEN) were also found to be statistically insignificant about the impact on the per capita income of households in the 
study area.

In contrast, those variables such as the gender of household heads (GENDER), household size (HSIZE), total household land area ( $L S I Z E)$, distance from households home to market center (DISTANCE), off-farm work (OFFWORK), guarantee in security land (LSECUR) and participating in credit activities (LOAN) has an impact on the average per capita income of the households.

Gender of households head ( GENDER) has negative and significant effect on incomes generated from farm households. Female-headed households on average earn 1.921 million VND higher incomes than male-headed households. The lower expected earnings with male-headed households may be proved because the lower probability of becoming involved in the off-farm work activities (worker in factories) than households who have female-headed households. This effect is significant at the $10 \%$ level. This result supported by finding from Nigeria by Yakubu et al. [30]; but opposite with finding from Myanmar of Nem Nei Lhing et al. [31], from Vietnam by Loan and Huong [32].

Our study also shows that household size has a strong impact on the living standards of households in the study area. On the one hand, there was a negative correlation between farm household's income and the size of the household. As the size increased by one member, the profits were seen to reduce corresponding with regression coefficient on the regression model about 3.183 million VND. This situation can be explained that the increased in the family size will put higher pressure to earn more to money for members for cover their basic needs cause increase in expenditure for food, clothes, health and in some case is educate because a larger number of children may need to go to school, thence limited funds for total households expenditures and lead to farm households with more member will have lower per capita income than other farm households. This results opposite with finding from Yemen of Safa [33], from and from Bangladesh by Rahman [34] because these results indicate that large size of household will supply more productive in term of labor force and has better opportunities to diversify their income from farm and off-farm activities. However, it also supported by finding from Vietnam by Nghi and Trinh [35], from Zambia by Banda [36], and from Kenya by Wanjiku [37] because these studies agree that households who have large-scale may be able to only bring a high per capita income if the dependency ratio in the household is small. In contrary, large household size will lead to low per capita income if the dependency ratio in households is high.

Land is one of the important inputs of the production process, especially agricultural production. Through farm households field survey results in the study area, mainly agricultural and forestry farm households, the results have pointed out that land size is an important factor affecting the average income of farm households in study area. With significant at the $1 \%$ level which means that a one extra hectare increase of land size of farm households it resulted in an increase in per capita income about 3.385 million VND $\mathrm{y}^{-1}$. This finding agrees with result from Yemen by Safa [33], from Myanmar of Nem Nei Lhing et al. [31], from 
Bangladesh by Rahman [34] Vietnam by Loan and Huong [32] and Hai [26]. These researches indicate that an increase in land area is clearly one of the solutions to help farmers improve their incomes besides addition to improving their occupation, credit, and other factors.

Distance to the nearest the market center was found to have a statistically significant and negative effect on farm households income; or on the other word it indicated that the households who have far away distance from their home to the markets corresponding to the lower the per capita income. With every kilometer of increased distance from households home to the market, per capita income of farm households will decrease corresponding by 1.618 million VND. The reason might be, the closer of the farm household is to the market center, the more opportunities to engage in non-farm activities to generate income, in addition, this would make them minimizes the transportation costs to the market place when households buy and selling agricultural products on the market and leads to increased farm household incomes. This results also supported by finding from Sudan by Hassan [38], from Eritrea by Teame and Woldu [39], from Kenya by Wanjiku [37].

Respondents show that off-farm work variable (OFFWORK) has positively correlated with the total income per capita variable. It means that in the condition of other factors that are constant, those farm households who have incomes from off-farm work activities may have a higher per capita income approximately 4.902 million VND per person $\mathrm{y}^{-1}$ than those with only income from agriculture activities. This results also supported by finding from Eritrea by Teame and Woldu [39], from Kenya by Wanjiku [37] when these author assert that diversifying income generation activities will help farmers improve their living standards better than focusing on agricultural production only; because agricultural activities are often accompanied by unstable risks and income, with a large idle time. If farm households could how to make use of this idle time to do other jobs such as working as hired labor, doing part-time job and business, they are likely improving their income.

The results from Table 3 also indicated that land ownership security also positive impact to farm household income in Bac Kan province at the $5 \%$ significance level. This means that households with land security are guaranteed seem to have a higher per capita income than the other group about 1.729 million VND $\mathrm{y}^{-1}$. This similar to observed by Wanjiku [37], when the author implies that farm households income improved significantly in the case of farm households are assured property rights of land.

The finding also shows that access to credit had a positive correlation to average income which means that if the other factors are constant, those who participated to rural credit are likely had higher income than those who did not participant. The income for those who had participant to credit was found to higher by 3.223 million VND $\mathrm{y}^{-1}$ than those who did not participant. This may be explained that any activity to generate income needs to have a sufficiently large 
amount of capital to make the activity continuous and uninterrupted [36] [39]. On the other hand, those households who borrow money from credit institutions to invest in production activities often have more work motivation to create more income to repay loans from banks; hence, they try to try to use their loans in the most effective way, avoiding waste [40]. This result was statistically significant at $99 \%$ confidence level.

Astonishingly, the impact of forest plantation on per capita income was found insignificant statistically in the models 2 and 3. This may be explained by the reasons: Firstly, the field survey results show that income from forest plantation in 2017 is uneven among households, some households exploitation the entire area of forest plantations that they planted in 2011 year; on the contrary, some households only exploitation a part of forest plantation area that they have in 2017 year, the remaining forest area is continued to be exploitation in the following years or conduct exploitation large timber after 12 to 15 years. Therefore, it leads to a deviation in the calculation of total income between households and effects on the regression results. Secondly, forest plantation is not the sole factor affecting households income in the study area; besides forest plantation, household's income is also contributed by many income sources such as income from crop, animal husbandry, off-farm work income, and it is influenced by other factors that showed in the regression model expanded 3. Thirdly, another important reason is that the households income survey data is often inaccurate, 1) due to the prolongation of the production cycle in afforestation activities, 2) or because households often do not declare their real income when interviewed. Moreover, the full calculation and accuracy of household income are also very difficult. Therefore, assessing the impact of plantation on income may lead to inaccurate results.

\section{Conclusions}

Through 720 observations selected from databases of VRAFC 2011 and the 2017 field survey of the author, using the OLS regression combined with DID method, the paper assesses the impact of forest plantation on household's income in rural areas of Bac Kan Province. Based on the theoretical basis, and previous studies on factors affecting household income, the paper conducts to build the best estimation model while the dependent variable used to represent household livelihood is per capita income. The independent variables are divided into three groups representing the characteristics of the household head, household and institutional and policies factors.

The results have shown that participation in forest plantation activities did not improve per capita income of households in the study area. However, although the paper did not find a positive impact of forest plantation on household income, it also demonstrated other factors affecting household income. These include the gender of households head, household size, land ownership, off-farm employment, land security, and credit. Hence, in the future, to improve income 
and the living standard of farmers, policymakers need to pay attention to these factors.

In fact, our results only provide evidence of the impact of forest plantation on household's income through the field survey on a short time with some native species. To understand the full potential of forest plantation needs to require conducting the impact of synthetic analysis and calculation after long years when the farmer implements exploitation activities timber in different years. Furthermore, the study results indicated that tenure reform and approach resources for forestry development play an important role in promoting afforestation and economic development forestry in the study area. Therefore, in the future, policymakers need to propose strategies to ensure true equality in approach resources received by households.

\section{Conflicts of Interest}

The authors declare no conflicts of interest regarding the publication of this paper.

\section{References}

[1] Byron, N. and Arnold, M. (1999) What Futures for the People of the Tropical Forests? World Development, 27, 789-805. https://doi.org/10.1016/S0305-750X(99)00025-X

[2] Mayers, J. and Vermeulen, S. (2002) Power from the Trees: How Good Forest Governance Can Help Reduce Poverty. Opinion: World Summit on Sustainable Development. IIED, London.

[3] IUCN (2003) Forests, Poverty and Development: The Contribution of Forests to the Millennium Development Goals and Poverty Reduction Strategies. The World Conservation Union, Gland.

[4] FAO (2006) Better Forestry, Less Poverty: A Practitioner's Guide. In: Forestry Paper, FAO, Roma, 22-26.

[5] Schirmer, J. (2006) Socio-Economic Impacts of Land Use Change to Plantation Forestry: A Review of Current Knowledge and Case Studies of Australian Experience. Proceedings of the 2006 IUFRO Forest Plantations Meeting, Charleston, 93-99.

[6] Derkyi, M., Insaidoo, T. and Ros, M. (2010) Forest and Tree-Based Livelihoods in Ghana's High Forest Zone: Reforestation Schemes. Tropenbos International Ghana, Information Sheet-Outputs of the "Governance for Sustainable Forest-Related Livelihoods" Project.

http://www.tropenbos.org/index.php/en/where-we-work/ghana/ghana-projects/gha na-project-forestand-tree-related-livelihood

[7] Sandewall, M., Ohlsson, B., Sandewall, R.K. and Viet, L.S. (2010) The Expansion of Farm-Based Plantation Forestry in Vietnam. Ambio, 39, 567-579. https://doi.org/10.1007/s13280-010-0089-1

[8] D’Amato, D., Rekola, M., Wan, M., Cai, D. and Toppinen, A. (2017) Effects of Industrial Plantations on Ecosystem Services and Livelihoods: Perspectives of Rural Communities in China. Land Use Policy, 63, 266-278. https://doi.org/10.1016/j.landusepol.2017.01.044

[9] Pirard, R., Petit, H. and Baral, H. (2017) Local Impacts of Industrial Tree Planta- 
tions: An Empirical Analysis in Indonesia across Plantation Types. Land Use Policy, 60, 242-253. https://doi.org/10.1016/j.landusepol.2016.10.038

[10] Sunderlin, W.D. and Huynh, T.B. (2005) Poverty Alleviation and Forests in Vietnam: CIFOR.

[11] Mcelwee, P.D. (2008) Forest Environmental Income in Vietnam: Household Socioeconomic Factors Influencing Forest Use. Environmental Conservation, 35, 147-159. https://doi.org/10.1017/S0376892908004736

[12] Naburs, G.-J., Schelhaas, M.-J., Orazio, C., Hengeveld, G., Tome, M. and Farrell, E.P. (2014) European Perspective on the Development of Planted Forests, Including Projections to 2065. New Zealand Journal of Forestry Science, 44, S8. https://doi.org/10.1186/1179-5395-44-S1-S8

[13] Szulecka, J., Pretzsch, J. and Secco, L. (2014) Paradigms in Tropical Forest Plantations: A Critical Reflection on Historical Shifts in Plantation Approaches. International Forestry Review, 16, 128-143. https://doi.org/10.1505/146554814811724829

[14] Andersson, K., Lawrence, D., Zavaleta, J. and Guariguata, M.R. (2016) More Trees, More Poverty? The Socioeconomic Effects of Tree Plantations in Chile, 2001-2011. Environmental Management, 57, 123-136. https://doi.org/10.1007/s00267-015-0594-X

[15] Kiyingi, I., Edriss, A., Phiri, M., Buyinza, M. and Agaba, H. (2016) The Impact of Farm Forestry on Poverty Alleviation and Food Security in Uganda. Journal of Sustainable Development, 9, 150. https://doi.org/10.5539/jsd.v9n1p150

[16] Salam, M.A., Noguchi, T. and Koike, M. (2000) Understanding Why Farmers Plant Trees in the Homestead Agroforestry in Bangladesh. Agroforestry Systems, 50, 77-93. https://doi.org/10.1023/A:1006403101782

[17] Nsiah, B. and Pretzsch, J. (2007) The Contribution of Smallholder Forest Plantation Development to the Livelihood of Farm Households in the High Forest Zone of Ghana. Tropentag, Witzenhausen.

[18] Sikor, T. and Baggio, J.A. (2014) Can Smallholders Engage in Tree Plantations? An Entitlements Analysis from Vietnam. World Development, 64, S101-S112. https://doi.org/10.1016/j.worlddev.2014.03.010

[19] Bleyer, M. (2015) Socio-Economic Impacts of Private Forest Investment on Local Livelihoods in Niassa, Mozambique.

[20] Committee, Bac Kan Provincial People's. https://www.Backan.Gov.Vn/Pages/Default.Aspx

[21] Phuc, N.T., Tri, T.M. and Son, V.V. (2013) Large-Scale Production Forest Plantation in Nam Dong District: Effective and Potential Model. Hue University Journal of Science, 72, 255-261.

[22] Pham, T.T., Bennett, K., Vu, T.P., Brunner, J., Ngoc, D.L. and Nguyen, D.T. (2013) Payments for Forest Environmental Services in Vietnam: From Policy to Practice. CIFOR Occasional Paper, No. 93.

[23] General Forestry Department (2014) Land and Forest Allocation in Viet Nam: Advantages and Disadvantages on Policies and Practices. General Forestry Department, Hanoi.

[24] Hung, T.V. (2014) Enhance the Capacity of the Wood Processing Industry in Vietnam to Meet the Needs of International Economic Integration. Journal of Development and Integration, 18, 71-76.

[25] Thuy, N.T.T.T. and Minh, P. (2015) Assist the Association in Undertaking a Strategic Research on the Development of the Wood Processing Industry. Vietnam 
Chamber of Commerce and Industry, Hanoi.

[26] Hai, L.D. (2017) The Factors Affecting the Income of Farmers in Ba Vi District, Hanoi. Journal Forestry Science and Technology_Forestry University, 4, 162-171.

[27] Kan, Department of Natural Resources and Environment of Bac. General Report, Department of Natural Resources and Environment of Bac Kan.

[28] Ainembabazi, J.H. and Angelsen, A. (2014) Do Commercial Forest Plantations Reduce Pressure on Natural Forests? Evidence from Forest Policy Reforms in Uganda. Forest Policy and Economics, 40, 48-56. https://doi.org/10.1016/j.forpol.2013.12.003

[29] Addis, F., Melak, S., Tefera, B. and Kassa, H. (2016) Impacts of Smallholder Tree Plantation in Amhara Region of Ethiopia: The Case of Lay Gayint and Fagta Locuma Districts. Ethiopian Journal of Economics, 25, 35-58.

[30] Bila, Y., Mshelia, B.S. and Landi, J.H. (2015) Off Farm Activities and Its Contribution to Household Income in Hawul Local Government Area, Borno State, Nigeria. Journal of Agriculture and Veterinary Science, 8, 9-13.

[31] Lhing, N.N., Nanseki, T. and Takeuchi, S. (2013) An Analysis of Factors Influencing Household Income: A Case Study of Pact Microfinance in Kyaukpadaung Township of Myanmar. American Journal of Human Ecology, 2, 94-102. https://doi.org/10.11634/216796221302320

[32] Loan, C.T.K. and Van Huong, N. (2015) Influence of Resources on Household Income in Thanh Hoa: Research in Tho Xuan and Ha Trung Districts. Journal of Science and Development, 13, 1051-1060.

[33] Safa, M.S. (2005) Socio-Economic Factors Affecting the Income of Small-Scale Agroforestry Farms in Hill Country Areas in Yemen: A Comparison of Ols and Wls Determinants. Small-Scale Forest Economics, Management and Policy, 4, 117-134.

[34] Rahman, S. (2017) Factors Influencing Household Income in Poor Urban Slum Settlements in Bangladesh.

[35] Nghi, N.Q. and Van Trinh, B. (2011) Factors Affecting the Income of Ethnic Minorities in the Mekong Delta. Science Journal of Can Tho University, 18, 240-250.

[36] Banda, M. (2012) An Assessment of the Factors That Affect Profitability of Cassava in Zambia's Chong We District. Department of Agricultural Economics and Extension of the University of Zambia, University of Zambia, Lusaka.

[37] Wanjiku, M.M. (2017) Factors Influencing Household Income in Unbound Project, Chiakariga County Assembly Ward, Tharaka-Nithi County, Kenya. Master, University of Nairobi, University of Nairobi, Nairobi.

[38] Hassan, T.A. (2015) Economic Analysis of Factors Affecting the Farmer Income under Traditional Farming System in South Darfur State-Sudan. Journal of Agricultural Science and Engineering, 1, 114-119.

[39] Teame, G.T. and Woldu, T.-Y.M. (2016) Factors Affecting Rural Households' Income Diversification: Case of Zoba Maekel, Eritrea. American Journal of Business, Economics and Management, 4, 7-15.

[40] Xuan, H.T.D. and Nam, M.V. (2011) Analyzing the Factors Affecting Income of Poultry Households in the Mekong Delta. Science Journal of Can Tho University, 17, 87-96. 


\section{Appendix}

\section{Appendix 1. Detecting and Correcting the Phenomenon of} Heteroskedasticity of Model 1

\begin{tabular}{lll}
\hline \multirow{2}{*}{ Variables } & \multicolumn{2}{l}{ Regression before correct HET Regression after correct HET } \\
\cline { 2 - 3 } & Coefficient & Coefficient \\
\hline CONSTANT & $15.057(8.41)^{* * *}$ & $15.057(10.15)^{* * *}$ \\
$T L A N T$ & $0.435(0.22)$ & $0.435(0.27)$ \\
$T$ & $-0.200(-0.08)$ & $-0.200(-0.10)$ \\
$T^{*}$ PLANT & $9.719(3.43)^{* * *}$ & $9.719(4.03)^{* * *}$ \\
& $\mathrm{n}=720$ & $\mathrm{n}=720$ \\
& $\mathrm{R}^{2}: 0.0885$ & $\mathrm{R}^{2}: 0.0885$ \\
& $\mathrm{R}^{2}$ Adjusted: 0.0847 & $\mathrm{R}^{2}$ Adjusted: 0.0847 \\
& Prob. $>$ Chi': 0.000 & Prob. $>$ Chi $i^{2}: 0.000$ \\
& F value: 23.17 & F value: 18.43 \\
Durbin-Watson: 1.332 & Durbin-Watson: 1.332 \\
\hline
\end{tabular}

Appendix 2. Detecting and Correcting the Phenomenon of Heteroskedasticity of Model 2

\begin{tabular}{|c|c|c|}
\hline \multirow{2}{*}{ Variables } & Regression before correct HET & Regression after correct HET \\
\hline & Coefficient & Coefficient \\
\hline CONSTANT & $23.659(7.47)^{* * *}$ & $23.659(7.66)^{* * *}$ \\
\hline PLANT & $-0.843(-0.58)$ & $-0.843(-0.70)$ \\
\hline$T$ & $3.621(1.96)$ & $3.621(2.34)$ \\
\hline$T^{*} P L A N T$ & $1.792(0.84)$ & $1.792(1.02)$ \\
\hline GENDER & $-1.932(-1.85)^{*}$ & $-1.932(-1.74)^{*}$ \\
\hline$A G E$ & $0.033(0.84)$ & $0.033(1.14)$ \\
\hline$E D U$ & $-0.041(-0.33)$ & $-0.041(-0.31)$ \\
\hline$H S I Z E$ & $-3.197(-9.14)^{* * *}$ & $-3.197(-7.59)^{* * *}$ \\
\hline$L S I Z E$ & $3.374(15.34)^{* * *}$ & $3.374(6.12)^{* * *}$ \\
\hline DISTAN & $-1.597(-7.16)^{* * *}$ & $-1.597(-7.53)^{* * *}$ \\
\hline OFFWORK & $5.063(5.23)^{* * *}$ & $5.063(5.33)^{* * *}$ \\
\hline LSECUR & $1.606(1.68)^{*}$ & $1.606(2.02)^{\star *}$ \\
\hline EXTEN & $0.065(0.44)$ & $0.065(0.30)$ \\
\hline \multirow[t]{7}{*}{$L O A N$} & $3.276(3.35)^{* * *}$ & $3.276(4.01)^{* * *}$ \\
\hline & $\mathrm{n}=720$ & $\mathrm{n}=720$ \\
\hline & $\mathrm{R}^{2}: 0.5341$ & $\mathrm{R}^{2}: 0.5341$ \\
\hline & $\mathrm{R}^{2}$ Adjusted: 0.5255 & $\mathrm{R}^{2}$ Adjusted: 0.5255 \\
\hline & Prob. > Chi²: 0.000 & Prob. > Chi': 0.000 \\
\hline & F-value: 62.26 & F-value: 38.45 \\
\hline & Durbin-Watson: 1.495 & Durbin-Watson: 1.495 \\
\hline
\end{tabular}


Appendix 3. Detecting and Correcting the Phenomenon of Heteroskedasticity of Model 3

\begin{tabular}{|c|c|c|}
\hline \multirow{2}{*}{ Variables } & Regression before correct HET & Regression after correct HET \\
\hline & Coefficient & Coefficient \\
\hline CONSTANT & $25.148(10.41)^{\star \star *}$ & $25.148(9.02)^{\star * *}$ \\
\hline PLANT & $-0.861(-0.59)$ & $-0.861(-0.71)$ \\
\hline$T$ & $3.559(1.93)$ & $3.559(2.30)$ \\
\hline$T^{*} P L A N T$ & $2.044(0.96)$ & $2.044(1.16)$ \\
\hline GENDER & $-1.921(-1.84)^{*}$ & $-1.921(-1.76)^{*}$ \\
\hline$H S I Z E$ & $-3.183(-9.16)^{\star * *}$ & $-3.183(-7.29)^{\star * *}$ \\
\hline$L S I Z E$ & $3.385(15.52)^{* * *}$ & $3.385(6.15)^{* * *}$ \\
\hline DISTAN & $-1.618(-7.33)^{\star * \star}$ & $-1.618(-7.28)^{\star \star \star}$ \\
\hline OFFWORK & $4.902(5.14)^{* \star *}$ & $4.902(5.13)^{\star * \star}$ \\
\hline LSECUR & $1.729(1.85)^{*}$ & $1.729(2.13)^{\star *}$ \\
\hline \multirow[t]{7}{*}{$L O A N$} & $3.223(3.31)^{* * *}$ & $3.223(3.96)^{* * *}$ \\
\hline & $\mathrm{n}=720$ & $\mathrm{n}=720$ \\
\hline & $\mathrm{R}^{2}: 0.5334$ & $\mathrm{R}^{2}: 0.5334$ \\
\hline & $\mathrm{R}^{2}$ Adjusted: 0.5269 & $\mathrm{R}^{2}$ Adjusted: 0.5269 \\
\hline & Prob. > Chi': 0.000 & Prob. > $\mathrm{Chi}^{2}: 0.000$ \\
\hline & F value: 81.06 & F value: 81.06 \\
\hline & Durbin-Watson: 1.496 & Durbin-Watson: 1.496 \\
\hline
\end{tabular}

Hypothesis: $\mathrm{H}_{0}$ : Non-heteroskedasticity

$\mathrm{H}_{1}$ : Heteroskedasticity

With a $5 \%$ significance level, Prob $>\mathrm{chi}^{2}=0.0000 \%$, so we should be able to reject the $\mathrm{H}_{0}$ hypothesis. This demonstrates that models had the phenomenon of Heteroskedasticity and have been corrected by the robust command in Stata (Results in Appendix 1,2 and 3).

\section{Appendix 4. Results the Statistical Significance Test of Removing AGE, EDU, EXTEN Variables from the Model 2}

\begin{tabular}{cc}
\hline No. & Indicator \\
\hline & Test $A G E E D U E X T E N$ \\
1 & $A G E=0$ \\
2 & $E D U=0$ \\
4 & $E X T E N=0$ \\
5 & $\mathrm{~F}(3,706)=0.55$ \\
\hline
\end{tabular}

Hypothesis: $\mathrm{H}_{0}: \hat{\beta}_{1}=\hat{\beta}_{2}=\hat{\beta}_{3}=0$

$\mathrm{H}_{1}: \hat{\beta} \neq 0$ 
With a $5 \%$ significance level, $\mathrm{P}$-value $(\mathrm{Prob})=65.13 \%$ indicated that it is impossible to reject the hypothesis $\mathrm{H}_{0}$, or these variables such as $A G E, E D U, E X T E N$ can be removed from the model.

\section{Appendix 5. The Test of Relevance of the Regression Model on the Relationship between per Capita Income and Forest Plantations and Other Factors}

Hypothesis $\mathrm{H}_{0}: \quad \hat{\beta}_{1}=\hat{\beta}_{2}=\hat{\beta}_{3}=\cdots=\hat{\beta}_{i}=0$

$\mathrm{H}_{1}: \quad \hat{\beta}_{i} \neq 0$

The regression results shown that in three regression models on the relationship between per capita income and forest plantation and other factors, the value of Prob $(\mathrm{F}$-statistic $)=0.000$, it always less than $1 \%$, this demonstrated that three models are statistically significant. In which, model 3 with adjusted $\mathrm{R}^{2}$ is $52.6 \%$, it approximately of model 2 and higher than adjusted $R^{2}$ of model 1 , so model 3 is the most suitable model.

Appendix 6. Test the Phenomenon of Multicollinearity

\begin{tabular}{ccc}
\hline Variable & VIF & $1 / \mathrm{VIF}$ \\
\hline PLANT & 2.02 & 0.496 \\
$T$ & 5.08 & 0.197 \\
$T^{\star}$ PLANT & 6.40 & 0.156 \\
GENDER & 1.05 & 0.954 \\
HSIZE & 1.15 & 0.871 \\
LSIZE & 1.35 & 0.738 \\
DISTAN & 1.32 & 0.759 \\
OFFWORK & 1.14 & 0.877 \\
LSECUR & 1.07 & 0.936 \\
LOAN & 1.33 & 0.750 \\
Mean VIF & 2.19 & - \\
\hline
\end{tabular}

VIF coefficient $<10$ indicated that there is no multicollinearity phenomenon in the model. 